\title{
Kemampuan Pemecahan Masalah Matematis Siswa SMP pada Materi SPLDV Ditinjau dari Kemampuan Awal Matematika (KAM)
}

\author{
Irma Purnamasari ${ }^{*}$, Wahyu Setiawan ${ }^{2}$ \\ ${ }^{1,2}$ IKIP Siliwangi \\ *irmapurnama13@gmail.com
}

Diterima: Januari 2019. Disetujui: Juni 2019. Dipublikasikan: Juli 2019.

\begin{abstract}
ABSTRAK
Kemampuan pemecahan masalah matematis adalah salah satu kemampuan yang harus dikuasai oleh siswa agar mampu secara matematis memecahkan masalah sering dijumpai di kehidupan nyata. Indikator kemampuan pemecahan masalah matematis meliputi mampu memahami masalah, merencanakan strategi pemecahan masalah, melakukan strategi atau prosedur pemecahan masalah, dan memeriksa kebenaran jawaban atau hasil yang diperoleh. Penelitian ini bertujuan untuk mengetahui kemampuan pemecahan masalah matematis siswa SMP ditinjau dari Kemampuan Awal Matematik (KAM). Metode yang digunakan pada penelitian ini adalah deksriptif. Subjek penelitian yaitu siswa kelas VIII F SMP Angkasa Lanud Sulaiman yang berjumlah 30 orang. Instrumen yang digunakan dalam penelitian berupa tes soal uraian kemampuan pemecahan masalah matematis sebanyak 5 soal. Analisis data yang digunakan dalam penelitian ini adalah dengan mengelompokkan siswa berdasarkan hasil Penilaian Tengah Semester (PTS) sebagai kemampuan awal siswa. Siswa dibagi menjadi tiga kelompok, yaitu kelompok KAM atas, kelompok KAM menengah dan kelompok KAM bawah. Hasil penelitian menunjukkan bahwa siswa kesulitan mengerjakan soal nomor 5 dan baik siswa kelompok KAM atas, KAM menengah maupun KAM bawah, siswa kurang menguasai indikator ke-4 yaitu memeriksa kebenaran jawaban.
\end{abstract}

Kata kunci: kemampuan awal matematika, kemampuan pemecahan masalah matematis.

\begin{abstract}
Mathematical problem solving ability is one of the abilities that must be mastered by students in order to be able to mathematically solve problems often found in real life. Indicators of mathematical problem solving capabilities include being able to understand problems, plan problem solving strategies, perform strategies or procedures for problem solving, and check the truth of answers or results obtained. This study aims to determine the mathematical problem solving abilities of junior high school students in terms of Early Mathematical Ability (KAM). The method used in this study is descriptive. The research subjects were class VIII F Space Junior High School Sulaiman Air Base which numbered 30 people. The instrument used in the study was a test of the questions about the mathematical problem solving abilities of 5 questions. Analysis of the data used in this study is to classify students based on the results of the Middle Semester Assessment (PTS) as students' initial abilities. Students are divided into three groups, namely the upper KAM group, the middle KAM group and the lower KAM group. The results showed that students had difficulty working on the number 5 questions and both the upper KAM group students, the middle KAM and the lower KAM students, students did not master the 4th indicator, namely checking the correctness of the answers.
\end{abstract}

Keywords: initial mathematical abilities, mathematical problem solving abilities.

How to Cite: Purnamasari, I. \& Setiawan, W. (2019). Kemampuan Pemecahan Masalah Matematis Siswa SMP pada Materi SPLDV Ditinjau dari Kemampuan Awal Matematika (KAM). Journal Of Medives : Journal Of Mathematics Education IKIP Veteran Semarang, 3(2), 207-215. 


\section{PENDAHULUAN}

Matematika merupakan salah satu mata pelajaran yang diajarkan di sekolah kepada siswa dan memiliki peran penting dalam pembentukan pola pikir manusia, khususnya dalam kehidupan nyata sehari-hari. Hal tersebut berkaitan dengan Hendriana (2014) yang mengemukakan bahwa, matematika memiliki peranan penting sebagai pembentuk pola pikir manusia yang cerdas dan terutama penting dalam masyarakat modern, karena dapat membuat manusia menjadi lebih fleksibel secara mental, terbuka dan mudah beradaptasi dengan berbagai situasi dan permasalahan. Karena itulah matematika dianggap sebagai mesin pencetak generasi yang unggul dan siap bersaing dengan perubahan.

Menurut Setiawan (2015) untuk meningkatkan kualitas pendidikan, sekolah dituntut untuk mempersiapkan peserta didik supaya memiliki berbagai macam kemampuan termasuk dalam pelajaran matematika, sehingga mereka dapat menjadi manusia yang berkualitas dan mampu bersaing. Diantaranya adalah kemampuan pemecahan masalah matematis. Ruseffendi (2006) mengemukakan bahwa kemampuan pemecahan masalah sangat penting dalam matematika, bukan saja bagi mereka yang di kemudian hari akan mendalami atau mempelajari matematika, melainkan juga bagi mereka yang akan menerapkannya dalam bidang studi lain dan dalam kehidupan sehari-hari.

Rianto et.al (2017) mengatakan dalam proses pembelajaran maupun dalam kehidupan sehari-hari, kemampuan pemecahan masalah ini sangat penting. Pemecahan masalah sebagai langkah awal siswa dalam mengembangkan ide-ide dalam membangun pengetahuan baru dan mengembangkan keterampilan-keterampilan matematika.. Menurut Tomo et.al. (2016) kemampuan ini sangat berguna bagi siswa pada saat mendalami matematika maupun dalam kehidupan sehari-hari. Soedjadi (Tomo et.al., 2016) berpendapat bahwa kemampuan pemecahan masalah merupakan suatu keterampilan pada diri peserta didik agar mampu secara matematis memecahkan masalah yang berhubungan dengan matematika atau dalam ilmu lainnya dan masalah yang sering dijumpai siswa di kehidupan nyata.

Menurut Branca (Hendriana \& Sumarmo, 2014) (Setiawan \& Andika Sari, 2018) pemecahan masalah termasuk salah satu kemampuan yang harus dikuasai oleh siswa, karenanya pemecahan masalah disebut sebagai jantungnya matematika. Melalui pemecahan masalah, diharapkan siswa dapat menemukan konsep matematika yang dipelajarinya. Kemudian menurut Dahar (Harahap, 2017) (Rojabiyah \& Setiawan, 2019), pemecahan masalah bukan sebagai suatu keterampilan generik, melainkan merupakan suatu kegiatan manusia yang menggabungkan antara konsep dan aturan yang sebelumnya telah diperoleh. Pernyataan tersebut mengandung makna ketika seseorang mampu untuk menyelesaikan suatu masalah, maka seseorang itu telah memiliki suatu kemampuan yang baru. Dapat disimpulkan, semakin banyaknya masalah yang dihadapi oleh seseorang dan ia dapat menyelesaikannya, maka 
semakin banyak kemampuan yang ia miliki. Hal itu dapat membantunya dalam mengarungi kehidupan seharihari.

Tahapan pemecahan masalah menurut Polya (Winarti, 2017), yaitu memahami masalah, menyusun rencana penyelesaian, melaksanakan rencana penyelesaian, dan memeriksa kembali prosedur dan hasil penyelesaian.

Terdapat beberapa faktor yang memengaruhi keberhasilan siswa dalam belajar matematika, diantaranya faktor internal yang meliputi kemampuan awal, tingkat kecerdasan, motivasi belajar, kebiasaan belajar, kecemasan belajar, motivasi belajar, dan sebagainya. Selain faktor internal, juga terdapat faktor eksternal diantaranya karena lingkungan keluarga, lingkungan sekolah, lingkungan masyarakat, keadaan sosial dan ekonomi dan lain sebagainya (Ahmadi dan Widodo, 2004).

Menurut Zuyyina et.al. (2018) kemampuan awal peserta didik adalah salah satu yang menentukan keberhasilan pembelajaran matematika. Setiap individu memiliki kemampuan belajar yang berbeda. Kemampuan awal peserta didik merupakan kemampuan yang sebelumnya sudah dimiliki oleh peserta didik dari sebelum mendapat pembelajaran. Ini juga menunjukkan kesiapan peserta didik dalam menerima materi baru yang disampaikan oleh guru. Hasil penelitian Hevriansyah \& Megawanti (2017) (Khadijah \& Setiawan, 2018) menunjukkan bahwa ada pengaruh yang signifikan antara kemampuan awal matematika dengan hasil belajar siswa.
Berdasarkan pengamatan peneliti di tempat Praktik Lapangan Profesi (PLP) di kelas VIII F SMP Angkasa Lanud Sulaiman, hasil Penilaian Tengah Semester (PTS) siswa tahun ajaran 2018/2019 pada pelajaran matematika hanya 2 orang dari 30 siswa yang mendapatkan nilai tuntas. Sedangkan, nilai siswa yang lainnya dibawah KKM (Kriteria Ketuntasan Minimal). Dimana standar nilai KKM di SMP Angkasa Lanud Sulaiman adalah 75. Dari data tersebut menunjukkan kemampuan siswa di sekolah tersebut dalam menyelesaikan soal matematika masih rendah.

Dari pemaparan di atas, muncul pemikiran untuk melakukan penelitian dalam menganalisis pemecahan masalah matematis siswa pada materi Sistem Persamaan Linear Dua Variabel (SPLDV) ditinjau dari KAM (Kemampuan Awal Matematika). Adapun tujuan dari penelitian ini adalah untuk menganalisis jawaban siswa dan mengetahui kemampuan pemecahan masalah matematis siswa pada materi SPLDV.

\section{METODE PENELITIAN}

Metode yang digunakan dalam penelitian ini yaitu penelitian survey, studi kasus pada siswa SMP Angkasa Lanud Sulaiman. Penelitian ini mendeskripsikan jawaban siswa dalam mengerjakan soal kemampuan pemecahan masalah matematis dilihat dari Kemampuan Awal Matematika (KAM). Subjek penelitian adalah siswa di kelas VIII F SMP Angkasa Lanud Sulaiman dengan jumlah 30 orang. Subjek kemudian dikelompokkan 
menjadi tiga kategori KAM berdasarkan hasil Penilaian Tengah Semester (PTS) tahun ajaran 2018/2019. Soal berupa tes objektif pilihan berganda berjumlah 15 soal. Dari hasil PTS yang diperoleh, selanjutnya diurutkan dari nilai yang paling tinggi sampai nilai terendah. Kemudian dari urutan tersebut siswa di bagi menjadi tiga kategori, yaitu siswa dengan kategori kelompok atas, kelompok menengah dan kelompok bawah. Pengelompokkan KAM ditentukan sebagai berikut.

Menurut Somakim (Novitasari, 2015) kriteria pengelompokkan kemampuan awal matematika siswa berdasarkan skor rata-rata $(\bar{x})$ dan simpangan baku (SB) sebagai berikut.

$\mathrm{KAM} \geq \bar{x}+\mathrm{SB}$

Siswa Kelompok Atas $\bar{x}-\mathrm{SB} \leq \mathrm{KAM}<\bar{x}+\mathrm{SB} \quad$ :

Siswa Kelompok Menengah $\mathrm{KAM}<\bar{x}-\mathrm{SB}$

Siswa Kelompok Bawah
Instrumen penelitian ini yaitu soal tes uraian kemampuan pemecahan masalah matematis yang diadopsi dan dimodifikasi dari Pudin (Hendriana et $a l ., 2017)$ yang terdiri dari 5 soal uraian dan telah divalidasi. Untuk indikator kemampuan pemecahan masalah yang digunakan adalah indikator menurut Polya (Winarti, 2017) yaitu: (1) memahami masalah; 2) menyusun strategi atau rencana penyelesaian; 3) menyelesaikan permasalahan sesuai rencana yang telah dibuat, dan 4) memeriksa kembali jawaban.

Pedoman penskoran pada setiap langkah dalam pemecahan masalah menggunakan rubrik penskoran diambil modifikasi dari Rosid \& Listyani (2014) yang dapat dilihat pada Tabel 1. Hasil penelitian dihitung dan dianalisis dengan menggunakan Ms. Excel 2016.

Tabel 1. Rubrik Skor Kemampuan Pemecahan Masalah Matematis

\begin{tabular}{|c|c|c|}
\hline Indikator Kemampuan Pemecahan Masalah & Respon & Skor \\
\hline \multirow{4}{*}{$\begin{array}{l}\text { Mengidentifikasi masalah, memahami masalah } \\
\text { dengan benar, menyebutkan apa yang diketahui dan } \\
\text { ditanya dalam masalah }\end{array}$} & $\begin{array}{ll}- & \text { Tidak mengerti sama sekali masalah yang dimaksud }\end{array}$ & 0 \\
\hline & $\begin{array}{l}\text { - Tidak mengerti sebagian masalah dengan menyebutkan } \\
\text { sebagian apa yang diketahui dan tidak menyebutkan } \\
\text { apa yang ditanyakan dari masalah }\end{array}$ & 1 \\
\hline & $\begin{array}{l}\text { Tidak mengerti sebagian masalah dengan menyebutkan } \\
\text { sebagian apa yang diketahui dan menyebutkan apa } \\
\text { yang ditanyakan dari masalah }\end{array}$ & 2 \\
\hline & $\begin{array}{l}\text { - Mampu mengidentifikasi masalah dengan benar dan } \\
\text { tepat }\end{array}$ & 3 \\
\hline \multirow{5}{*}{$\begin{array}{l}\text { Merencanakan penyelesaian masalah, menyatakan } \\
\text { dan menuliskan model atau rumus yang digunakan } \\
\text { untuk menyelesaikan masalah }\end{array}$} & - $\quad$ Tidak merencanakan masalah sama sekali & 0 \\
\hline & $\begin{array}{l}\text { - Merencanakan penyelesaian masalah tetapi tidak benar } \\
\text { (tidak sesuai dengan masalah sama sekali) }\end{array}$ & 1 \\
\hline & $\begin{array}{l}\text { - Merencanakan penyelesaian yang digunakan hanya } \\
\text { sebagian saja yang benar }\end{array}$ & 2 \\
\hline & $\begin{array}{l}\text { - Merencanakan penyelesaian yang digunakan hanya } \\
\text { sebagian saja yang benar }\end{array}$ & 3 \\
\hline & $\begin{array}{l}\text { - Mampu merencanakan penyelesaian masalah dengan } \\
\text { benar dan tepat }\end{array}$ & 4 \\
\hline \multirow{5}{*}{$\begin{array}{l}\text { Menyelesaikan masalah sesuai dengan rencana, } \\
\text { melakukan operasi hitung dengan benar }\end{array}$} & - $\quad$ Tidak mampu menyelesaikan masalah sama sekali & 0 \\
\hline & Menyelesaikan masalah tidak sesuai dengan rencana & 1 \\
\hline & - $\quad$ Menyelesaikan sebagian dari masalah & 2 \\
\hline & - $\quad$ Menyelesaikan masalah kurang tepat & 3 \\
\hline & Mampu menyelesaikan masalah dengan benar dan tepat & 4 \\
\hline \multirow{3}{*}{$\begin{array}{l}\text { Mengevaluasi, menarik kesimpulan dari jawaban } \\
\text { yang diperoleh dan mengecek kembali perhitungan } \\
\text { yang diperoleh }\end{array}$} & Tidak menyimpulkan masalah sama sekali & 0 \\
\hline & Dapat menyimpulkan masalah tetapi kurang tepat & 1 \\
\hline & - $\quad$ Dapat menyimpulkan masalah dengan tepat & 2 \\
\hline
\end{tabular}


HASIL DAN PEMBAHASAN

Hasil Penilaian Tengah Semester (PTS) dikelompokkan menjadi tiga kategori KAM, selanjutnya dilakukan tes kemampuan pemecahan masalah matematis siswa.

Tabel 2. Presentase Siswa Berdasarkan Kategori KAM dalam Menjawab Soal Pemecahan Masalah Matematis

\begin{tabular}{cccccc}
\hline \multirow{2}{*}{$\begin{array}{c}\text { Kategori } \\
\text { KAM }\end{array}$} & \multicolumn{5}{c}{$\begin{array}{c}\text { Presentase Menjawab Soal } \\
\text { dengan Benar }\end{array}$} \\
\cline { 2 - 5 } No. 1 & No. 2 & No. 3 & No. 4 & No. 5 \\
\hline $\begin{array}{c}\text { Klompok } \\
\text { Atas }\end{array}$ & $82 \%$ & $78 \%$ & $56 \%$ & $65 \%$ & $47 \%$ \\
$\begin{array}{c}\text { Kelompok } \\
\text { Menengah }\end{array}$ & $77 \%$ & $62 \%$ & $55 \%$ & $58 \%$ & $28 \%$ \\
$\begin{array}{c}\text { Kelompok } \\
\text { Bawah }\end{array}$ & $68 \%$ & $58 \%$ & $48 \%$ & $34 \%$ & $5 \%$ \\
\hline
\end{tabular}

Dari Tabel 2, didapat hasil yang paling tinggi dari presentase siswa menjawab soal dengan benar di ketiga kelompok terdapat pada soal nomor 1 . Dengan hasil presentase siswa pada kelompok atas menjawab benar $78 \%$, siswa kelompok menengah menjawab soal dengan benar $71 \%$ dan siswa pada kelompok bawah menjawab benar $60 \%$. Dari hasil yang disebutkan, menunjukkan soal nomor 1 tergolong soal yang mudah. Sedangkan, presentase yang paling rendah dari semua indikator terdapat pada indikator kelima yaitu pada soal nomor 5. Siswa kelompok atas hanya $21 \%$ yang menjawab dengan benar, siswa kelompok menengah hanya $21 \%$ yang menjawab benar dan siswa kelompok bahwa hanya $2 \%$ yang menjawab benar. Ini menunjukkan siswa mengalami kesulitan dalam menyelesaikan soal nomor 5 dibandingkan soal yang lain.
Sedangkan untuk indikator, Tabel 3 menunjukkan hasil analisis kebenaran siswa dalam menjawab dan mengerjakan sesuai indikator pemecahan masalah menurut Polya dan dimodifikasi dengan rubrik penskoran dari Rosid \& Listyani (2014).

Tabel 3. Persentase Siswa dalam Menjawab Soal Kemampuan Pemecahan Masalah Sesuai Tahapan Menurut Polya

\begin{tabular}{ccccc}
\hline & I1 & $\mathbf{I 2}$ & $\mathbf{I 3}$ & $\mathbf{I 4}$ \\
\hline $\begin{array}{c}\text { Kelompok } \\
\text { Atas } \\
\text { Kelompok }\end{array}$ & $88 \%$ & $88 \%$ & $75 \%$ & $25 \%$ \\
$\begin{array}{c}\text { Menengah } \\
\text { Kelompok } \\
\text { Bawah }\end{array}$ & $60 \%$ & $40 \%$ & $20 \%$ & $0 \%$ \\
\hline Keterangan: I = Indikator & & & \\
\hline
\end{tabular}

Berdasarkan Tabel 3, terlihat bahwa persentase yang paling rendah adalah pada indikator ke 4. Siswa kelompok atas hanya $25 \%$ siswa yang menjawab benar, pada siswa kelompok menengah hanya $16 \%$ siswa yang menjawab benar dan pada siswa kelompok bawah tidak ada sama sekali. Ini menunjukkan bahwa siswa mengalami kesulitan dalam tahapan memeriksa kembali hasil atau jawaban.

Berdasarkan Tabel 2 dan 3, karena soal yang paling rendah persentasenya dari siswa yang menjawab benar adalah soal nomor 5, maka akan kita bahas soal nomor 5 .

Soal Nomor 5. Soal diadopsi dari Pudin (Hendriana, et. al., 2016.).

Di toko "SERBA ADA", Ibu Cindy membeli satu kilogram apel dan dua kilogram pear seharga $\mathrm{Rp}$. 60.000,-. $\mathrm{Bu}$ Lili membeli tiga 
kilogram apel dan empat kilogram pear harganya Rp. 130.000,-. Periksa apakah harga apel Rp. $9.000,-/ \mathrm{kg}$ dan harga pear $\mathrm{Rp}$. $25.000,-/ \mathrm{kg}$ merupakan solusi dari permasalahan di atas, jelaskan!

Gambar 1 adalah jawaban salah satu siswa kategori kelompok atas.

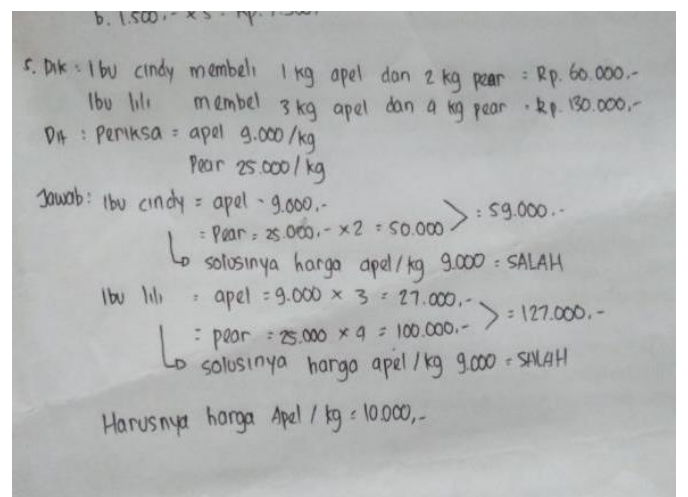

Gambar 1. Jawaban Siswa S-9 Kelompok Atas dalam Menyelesaikan Soal Ke-5

Dari Gambar 1, sampel S-9 kelompok atas pada indikator ke 5 yaitu memeriksa kebenaran jawaban, siswa memeriksa kembali informasi pada permasalahan dengan cara menghitung ulang masing-masing buah yang dibeli oleh Ibu Cindy dan Ibu Lily. Siswa menuliskan bahwa kebenaran jawaban tersebut adalah "SALAH". Lalu, siswa menuliskan solusi dari permasalahan, dengan jawaban harusnya harga apel/kg $=10.000,-$. Untuk indikator memeriksa kembali jawaban, seharusnya setelah memberikan solusi bahwa harga apel adalah Rp.10.000,-/kg maka siswa membuktikan dengan cara menghitung kembali jika harga apel Rp.10.000,adalah solusi dari permasalahan tersebut. Tetapi, jawaban siswa masih kurang untuk indikator memeriksa kebenaran jawaban. Karena siswa belum menuliskan berapa harga pear/kg untuk solusi permasalahan tersebut.

Jawaban lain dari siswa kelompok menengah dapat dilihat pada Gambar 2.

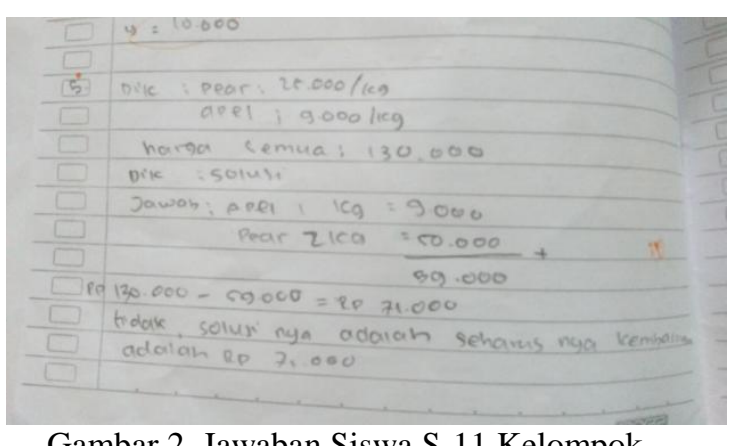

Gambar 2. Jawaban Siswa S-11 Kelompok Menengah dalam Menyelesaikan Soal Ke-5

Dari Gambar 2, siswa S-11 kelompok menengah mengerjakan soal dengan cara menuliskan informasi yang diketahui dan ditanya terlebih dahulu baru kemudian menjawab soal. Siswa S11 tidak menyusun model matematika. Siswa S-11 langsung mencoba menjumlahkan harga $1 \mathrm{~kg}$ apel dan $3 \mathrm{~kg}$ pear, setelah itu ia mencari selisih dari 4 kg pear dikurangi jumlah $1 \mathrm{~kg}$ apel dan 3 $\mathrm{kg}$ pear. Berdasarkan jawaban yang ditulis oleh siswa terlihat bahwa siswa belum memahami masalah dengan baik sehingga siswa tidak menyusun startegi dan menyelesaikan masalah dengan tepat. Siswa S-11 tidak menuliskan solusi dari masalah yang diberikan, yaitu berapa harga apel dan pear akan tetapi siswa S-11 menuliskan uang kembalian.

Gambar 3 menunjukkan jawaban salah satu siswa kelompok bawah.

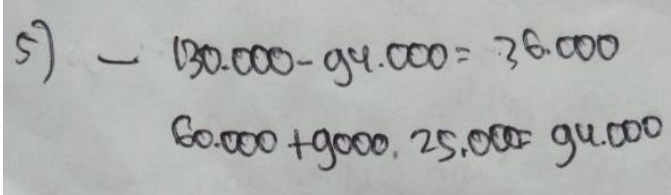

Gambar 3. Jawaban Siswa S-25 Kelompok Bawah dalam Menyelesaikan Soal Ke-5 
Dari gambar 3, salah satu siswa kelompok bawah yaitu siswa S-25 tidak menuliskan langkah-langkah pengerjaannya. Siswa belum menuliskan informasi yang diketahui dan ditanyakan pada soal. Siswa juga tidak merencanakan strategi penyelesaian dengan tepat dan tidak menemukan solusi dari masalah yang Siswa S-25 langsung menuliskan operasi hitung dengan bilangan-bilangan yang tertera di soal namun tanpa prosuder yang jelas mengapa bilangan-bilang tersebut dioperasikan. Siswa S-25 belum memahami soal , tidak menyusun dan melaksanakan rencana penyelesaian, serta tidak mengetahui dan tidak menyimpulkan solusi dari kebenaran jawaban.

Berdasarkan uraian jawaban siswa dari setiap kelompok KAM di atas, terlihat bahwa siswa dari setiap kelompok belum mampu mengerjakan indikator memeriksa kebenaran jawaban dengan baik. Meskipun demikian, terdapat perbedaan proses berpikir antara siswa kelompok KAM atas, KAM menengah, dan KAM bawah. Siswa kelompok KAM atas sudah mampu memahami masalah dengan baik, siswa juga sudah mampu menemukan solusi dari masalah meskipun belum sepenuhnya benar. Berbeda dengan siswa kelompok KAM menengah dan bawah yang gagal memahami masalah dengan baik sehingga siswa gagal menemukan solusi yang tepat. Siswa kelompok KAM menengah meskipun tidak menemukan solusi yang tepat tetapi siswa dapat memahami sebagian informasi dari soal, berbeda dengan kelompok KAM bawah yang tidak memahami soal sama sekali.
Berdasarkan jawaban siswa pada tes kemampuan pemecahan masalah, terdapat beberapa faktor yang dapat mempengaruhi kemampuan pemecahan masalah siswa, antara lain kemampuan pemahaman siswa terhadap masalah yang diberikan masih kurang sehingga siswa tidak mampu merencanakan strategi penyelesaian dan menemukan solusi yang tepat. Hal ini sejalan dengan penelitian Sulistyorini \& Setyaningsih (2016) bahwa siswa kesulitan memahami masalah karena siswa tidak biasa mengerjakan soal cerita dengan langkah pemecahan masalah dengan tahapan undikator menurut Polya. Faktor lainnya adalah siswa belum memahami konsep esensial materi SPLDV sehingga siswa tidak menerapkannya untuk menyelesaikan masalah yang diberikan.

Hasil penelitian ini menunjukkan bahwa siswa dengan kelompok KAM atas memiliki kemampuan pemecahan masalah matematis pada tahap memahami masalah, menyusun strategi dan menyelesaikan strategi penyelesaian masalah yang lebih baik dibandingkan siswa kelompok KAM menengah dan siswa kelompok KAM bawah. Akan tetapi, baik siswa pada KAM atas, KAM menengah maupun KAM bawah, siswa kurang menguasai indikator ke-4 yaitu memeriksa kebenaran jawaban. Hal ini sejalan dengan penelitian Sulistyorini \& Setyaningsih (2016) yang menyatakan bahwa kesulitan siswa saat melihat kembali atau pada indikator memeriksa kembali jawaban, siswa tidak tahu cara memeriksa kembali dengan benar, siswa tidak dapat mengatur waktu pengerjaan dengan baik dan siswa malas untuk mengecek kembali jawaban. 


\section{PENUTUP}

Berdasarkan hasil analisis data dalam penelitian ini, siswa kesulitan dalam mengerjakan soal nomor 5. Hasil penelitian ini menunjukkan bahwa siswa dengan kelompok KAM atas memiliki kemampuan pemecahan masalah matematis pada tahap memahami masalah, menyusun strategi dan menyelesaikan strategi penyelesaian masalah yang lebih baik dibandingkan siswa kelompok KAM menengah dan siswa kelompok KAM bawah. Akan tetapi, baik siswa pada KAM atas, KAM menengah maupun KAM bawah, siswa kurang menguasai indikator ke-4 yaitu memeriksa kebenaran jawaban.

\section{DAFTAR PUSTAKA}

Harahap, E. R. (2017). Kemampuan Pemecahan Masalah Matematis Siswa Kelas VII Dalam Menyelesaikan Persamaan Linear Satu Variabel. Edumatica, 07(April), $44-54$

Hendriana, H. (2014). Membangun Kepercayaan Diri Siswa Melalui Pembelajaran Matematika Humanis. Jurnal Pengajaran Matematika Dan Ilmu Pengetahuan Alam, 19(1), 52. https://doi.org/10.18269/jpmipa.v19i 1.424

Hendriana, H., \& Sumarmo, U. (2014). Penilaian Pembelajaran Matematika. In PT Refika Aditama. Bandung.

Hevriansyah, P., \& Megawanti, P. (2017). Pengaruh Kemampuan Awal terhadap Hasil Belajar Matematika. JKPM (Jurnal Kajian Pendidikan Matematika), 2(1), 37. https://doi.org/10.30998/jkpm.v2i1.1 893
Khadijah, I. N. A., \& Setiawan, W. (2018). Analisis Kemampuan Komunikasi Matematis Siswa SMP Pada Materi Statistika. Jurnal Pembelajaran Matematika Inovatif, 1(6), 1095-1104.

Novitasari, D. (2015). Penerapan Pendekatan Creative Problem Solving (CPS) Sebagai Upaya Meningkatkan Kemamouan Berpikir Kritis Matematis Siswa. Jurnal Pendidikan Matematika \& Matematika, 1(1), 43-56.

Rianto, V. M., Yusmin, E., \& Nursangaji, A. (2017). Kemampuan Pemecahan Masalah Siswa Berdasarkan Teori John Dewey pada Materi Trigonometri. Jurnal Pendidikan Matematika FKIP Untan, 6(7).

Rojabiyah, A. B., \& Setiawan, W. (2019). Analisis Minat Belajar Siswa MTS Kelas VII dalam Pembelajaran Matematik Materi Aljabar Berdasarkan Gender. Journal On Education, 01(02), 458-464.

Rosid, M. A., \& Listyani, E. (2014). Kemampuan Awal Pemecahan Masalah SPLDV Siswa SMP. Jurnal Pendidikan Matematika Dan Sains, 1-13.

Ruseffendi, E. . (2006). Pengantar Kepada Membantu Guru Mengembangkan Kompetensinya dalam Pengajaran Matematika untuk Meningkatkan CBSA Main Author. Bandung: Tarsito.

Setiawan, W., \& Andika Sari, V. T. (2018). Pengembangan Bahan Ajar Konsep Diferensial Berbasis Konflik Kognitif. Jurnal Elemen, 4(2), 204. https://doi.org/10.29408/jel.v4i2.511 
Sulistyorini, S., \& Setyaningsih, N. (2016). Analisis Kesulitan Siswa dalam Pemecahan Masalah Soal Cerita Matematika Siswa SMP.

Tomo, Yusmin, E., \& Riyanti, S. (2016). Kemampuan Pemecahan Masalah Siswa pada Materi Bangun Datar di SMP. 5(5)(1), 1-11.

Winarti, D. (2017). Kemampuan Pemecahan Masalah Siswa Dalam Menyelesaikan Soal Cerita Berdasarkan Gaya Belajar Pada Materi Pecahan di SMP. Jurnal Pendidikan Dan Pembelajaran, 6(6), 1-9.

Zuyyina, H., Wijaya, T. T., \& Senjawati, E. (2018). Materi Lingkaran. 4(2), 79-90. 